Institute of $\mathbf{F}_{\text {ood and }} \mathbf{A}_{\text {gricultural }} \mathbf{S}_{\text {ciences }}$

\title{
Cultural Guidelines for Commercial Production of Interiorscape Ficus ${ }^{1}$
}

Jianjun Chen, Dennis B. McConnell, Richard J. Henny, and Kelly C. Everitt ${ }^{2}$

The genus Ficus, (Latin for fig), is a member of the family Moraceae and contains over 800 species. Figs are woody trees, shrubs, or vines native to Asia, Australia, and Africa. Cultivated species either produce edible fruit or possess ornamental value. This article describes common species and cultivars in the foliage plant industry (see Table 2), provides guidelines for their culture and interior use, and lists physiological problems that may be encountered during production and interiorscape use (see Table $3)$.

\section{Cultural Guidelines}

\section{Propagation}

Rooting of cuttings, air layering, and tissue culture are primary methods of fig propagation. Air layering or cuttings are mainly used for large specimens, whereas tissue culture propagated liners are used for producing figs in 10-inch or smaller containers. Due to the difficulty in rooting and tissue culture, F. binnendijkii 'Amstel King' is still propagated by air layering.

\section{Production}

Sphagnum peat, pine bark, vermiculate, or perlite can be volumetrically combined to formulate media for Ficus production. Ficus requires media with good container capacity and aeration, $\mathrm{pH}$ of 5.5-7, and soluble salts of 1-2 dS/m. Media may contain 10-20\% coarse sand to keep plants from wind tipping. Excessive root growth beneath the containers should be trimmed regularly. Cease trimming roots one month before shipment because damage to roots at that time will shock the plant and affect interior performance.

Ficus should be grown in a shadehouse with a temperature of 70 to $95^{\circ} \mathrm{F}$ and a relative humidity of 60 to $100 \%$. Either controlled-released or water-soluble fertilizers with micronutrients, or a combination of both can be used for Ficus production. The appropriate ratio of $\mathrm{N}: \mathrm{P}: \mathrm{K}$ should be $3: 1: 2$ or $3: 1: 3$. The suggested application rate is $3 \mathrm{lbs}$ $\mathrm{N}$ per $1,000 \mathrm{sq} f t$ per month. Table 2 provides a guide for determining whether figs are appropriately fertilized based on leaf analysis. It is advisable to stop fertilizing one month before shipment. Ficus require plenty of water. Irrigate frequently during hot weather.

1. This document is ENH879, one of a series of the Environmental Horticulture Department, Institute of Food and Agricultural Sciences, University of Florida. First published: March 2003. Please visit the EDIS web site at http://edis.ifas.ufl.edu

2. Jianjun Chen, Assistant Professor, Mid-Florida Research and Education Center and Environmental Horticultural Department, Dennis B. McConnell, Professor, Environmental Horticultural Department, Richard J. Henny, Professor, Mid-Florida Research and Education Center and Environmental Horticultural Department, and Kelly C. Everitt, Research Assistant, Mid-Florida Research and Education Center at the Institute of Food and Agricultural Sciences, University of Florida.

The Institute of Food and Agricultural Sciences is an equal opportunity/affirmative action employer authorized to provide research, educational information and other services only to individuals and institutions that function without regard to race, color, sex, age, handicap, or national origin. For information on obtaining other extension publications, contact your county Cooperative Extension Service office. Florida Cooperative Extension Service/Institute of Food and Agricultural Sciences/University of Florida/Christine Taylor Waddill, Dean. 
Table 1. Nutrient concentrations in leaves considered low, medium, or high for Ficus growth.

\begin{tabular}{||l|l|l|l||}
\hline \hline Nutrient & Low & Medium & High \\
\hline Nitrogen (\%) & $<1.5$ & $1.5-3.5$ & $>3.5$ \\
\hline Phosphorus (\%) & $<0.1$ & $0.1-0.5$ & $>0.5$ \\
\hline Potassium (\%) & $<1.0$ & $1.0-3.0$ & $>3.0$ \\
\hline Calcium (\%) & $<0.8$ & $0.8-2.5$ & $>2.5$ \\
\hline Magnesium (\%) & $<0.2$ & $0.2-1.0$ & $>1.0$ \\
\hline Sulfur (\%) & $<0.1$ & $0.1-0.5$ & $>0.5$ \\
\hline Iron (ppm) & $<40$ & $40-200$ & $>200$ \\
\hline Manganese (ppm) & $<20$ & $20-200$ & $>200$ \\
\hline Zinc (ppm) & $<10$ & $10-200$ & $>200$ \\
\hline Copper (ppm) & $<5$ & $5-25$ & $>25$ \\
\hline Boron (ppm) & $<20$ & $20-50$ & $>50$ \\
\hline \hline
\end{tabular}

Ficus can grow at light levels varying from deep shade to full sun. However, Ficus is sensitive to radical changes in light intensities, particularly from production shadehouse to interior low light conditions. To produce superior interiorscapeable trees, two common procedures have been used in plant production. One is to initially grow them under $50 \%$ shade (about 6,250 foot candles), and then acclimatize them under $80-90 \%$ shade (about 2,500 to 1,250 foot candles) for at least two months before using them for interiorscaping. The other is to initially grow them under $70-80 \%$ shade $(3,750$ to 2,500 foot candles) until they are ready for interior use.

Results from our recent studies may assist with the choice of light levels for Ficus production. Nine cultivars: 'Florida Spire', 'Indigo', 'Midnight', 'Midnight Princess', 'Monique', and 'Winter Green' of Ficus benjamina, 'Cabernet' and 'Melany' of $F$. elastica, and 'Alii' of $F$. binnendijkii were grown to marketable size from cuttings or tissue cultured liners. The cultivars were grown under three different light conditions: 50,70 , or $80 \%$ shade $(6,250,3,750$, or 2,500 foot candles). We then evaluated them for indoor performance in conditioning rooms with low light levels of 50 and 100 foot candles for one year. Data showed that plants produced under $70-80 \%$ shade were not only significantly larger and had better leaf color but also performed better under interior light levels of 100 or 50 foot candles than plants produced under $50 \%$ shade.

\section{Shipping and Interior Care}

Ficus should be shipped at a temperature of $55-65^{\circ} \mathrm{F}$. Once plants are placed indoors, it is advisable not to move, prune, re-pot, or fertilize them for about four weeks at least because plants do not need additional stresses. However, only those plants produced continuously under light levels $70 \%$ or lower or produced under relatively high light levels but acclimatized under $80 \%$ shade for at least two months are suitable for interior use under light levels of 100 to 200 foot candles. 'Alii' may be used under 50 foot candles. Plants should not be fertilized if soluble salts are $1.0 \mathrm{dS} / \mathrm{m}$ or more when solution is extracted by the pour-through method. If soluble salt levels are higher than $3.0 \mathrm{dS} / \mathrm{m}$, leaching the media may help reduce potential leaf burning problems. Media should be kept moist. Temperatures of 65 to $80^{\circ} \mathrm{F}$ are most appropriate, and drafts should be avoided. Proper pruning is usually necessary to maintain shape, thin foliage for better light penetration, and remove dead branches. 
Table 2. A listing of cultivars by species available in Florida as of 2002.

\begin{tabular}{|c|c|c|}
\hline Species & Cultivar & Characteristics \\
\hline F. benjamina & $\begin{array}{l}\text { 'Florida Spire', 'Indigo', 'Jacqueline', } \\
\text { 'Midnight', 'Monique', 'Natasja', } \\
\text { 'Spearmint', 'Stacey', 'Starlight', 'Too } \\
\text { Little', 'Variegata', 'Wiandi', 'Window } \\
\text { Pane', 'Wintergreen' }\end{array}$ & $\begin{array}{l}\text { The most abundant. A small shrub or tree with } \\
\text { adventitious roots and glossy leaves. Tolerance } \\
\text { to and conditioning for interior light levels varies } \\
\text { from cultivar to cultivar. }\end{array}$ \\
\hline $\begin{array}{l}\text { F. binnendijkii } \\
\text { Perhaps F. binnendykii }\end{array}$ & 'Alii' or 'Sabre', 'Amstel King' & $\begin{array}{l}\text { A shrub or tree with long, saber-shaped leaves } \\
\text { that are red when they first emerge. }\end{array}$ \\
\hline F. elastica & $\begin{array}{l}\text { 'Burgundy', 'Cabernet', 'Decora', } \\
\text { 'Robusta', 'Sylvie' }\end{array}$ & $\begin{array}{l}\text { A sparse shrub or tree with large, waxy, dark } \\
\text { purplish-green leaves. }\end{array}$ \\
\hline F. lyrata & $\begin{array}{l}\text { 'Fiddle-Leaf', 'Compacta', 'Everglades', } \\
\text { 'Suncoast Compacta' }\end{array}$ & $\begin{array}{l}\text { A large shrub or tree with large, coriaceous leaves } \\
\text { that resemble the body of a fiddle. }\end{array}$ \\
\hline $\begin{array}{l}\text { F. microcarpa } \\
\text { Formerly } \\
\text { F. nitida }\end{array}$ & 'Hawaii', 'Kay', 'Nitida' & $\begin{array}{l}\text { Tree forms used outdoors in tropical regions but } \\
\text { commonly used as a bonsai indoors. }\end{array}$ \\
\hline F. pumila & 'Creeping Fig', 'Snowflake' & $\begin{array}{l}\text { A vine that is often used in cooler interiorscape } \\
\text { locations. }\end{array}$ \\
\hline F. retusa & 'Kingman' & Thick trunk. Popular as bonsai. \\
\hline F. rubiginosa & 'Rusty Fig' & $\begin{array}{l}\text { Low spreading shrub with rust-red coloring on leaf } \\
\text { undersurfaces. }\end{array}$ \\
\hline $\begin{array}{l}\text { F. salicifolia } \\
\text { Formerly F. neriifolia }\end{array}$ & 'Willow-Leaf Fig' & $\begin{array}{l}\text { Resembles a willow tree and is very popular with } \\
\text { bonsai artists. }\end{array}$ \\
\hline
\end{tabular}

Table 3. Causes and effects of various physiological problems.

\begin{tabular}{||l|l|l||}
\hline \hline Symptoms & Probable Cause & Treatment \\
\hline Loss of lower leaves only & Age & Prune to shape. \\
\hline Yellowing of leaf edges & Underfeeding & $\begin{array}{l}\text { Increase fertilizer rate or application } \\
\text { frequency. }\end{array}$ \\
\hline Dry and shriveled leaves & $\begin{array}{l}\text { Low relative humidity or too much } \\
\text { sunlight }\end{array}$ & $\begin{array}{l}\text { Increase relative humidity or remove from } \\
\text { bright area. }\end{array}$ \\
\hline $\begin{array}{l}\text { Twig dieback } \\
\text { whomopsis, a fungus brought about by stress }\end{array}$ & $\begin{array}{l}\text { Remove dead twigs with sterilized shears, } \\
\text { spray affected plant part with a thiophanate } \\
\text { methyl fungicide, and avoid water stress. }\end{array}$ \\
\hline $\begin{array}{l}\text { Yellow leaf drop, small red } \\
\text { spots on the undersides of } \\
\text { leaves, bent branches }\end{array}$ & Moisture stress & \begin{tabular}{l} 
Adjust watering. \\
\hline Green leaf drop
\end{tabular} \\
\hline \hline
\end{tabular}


Table 3. Causes and effects of various physiological problems.

\begin{tabular}{|c|c|c|}
\hline Green leaf drop & Low light stress & Move plant to a brighter area. \\
\hline Green leaf drop & $\begin{array}{l}\text { Mercury }(\mathrm{Hg}) \text { exposure, usually due to } \\
\text { a newly painted area }\end{array}$ & Remove plant from area. \\
\hline $\begin{array}{l}\text { Excess leaf drop, leaves are } \\
\text { pale green, leaves are } \\
\text { V-shaped, branches are stiff } \\
\text { with narrow angles }\end{array}$ & $\begin{array}{l}\text { Plant was produced under high light } \\
\text { intensity }\end{array}$ & $\begin{array}{l}\text { Place plant in higher light area and } \\
\text { gradually acclimate to lower light levels. }\end{array}$ \\
\hline $\begin{array}{l}\text { Loss of oldest leaves, stunted } \\
\text { growth, new growth is darker } \\
\text { then turns yellow, shriveled } \\
\text { roots }\end{array}$ & High soluble salts & $\begin{array}{l}\text { Reduce fertilization, use water with low } \\
\text { soluble salt levels and leach soil. }\end{array}$ \\
\hline $\begin{array}{l}\text { Necrosis or chlorosis of the } \\
\text { old leaf margins }\end{array}$ & Potassium deficiency (K) & $\begin{array}{l}\text { Add potassium chloride or potassium nitrate } \\
\text { to the soil at recommended rate. }\end{array}$ \\
\hline $\begin{array}{l}\text { Interveinal chlorosis in } \\
\text { terminal leaves, especially in } \\
\text { F. nitida }\end{array}$ & Manganese deficiency (Mn) & $\begin{array}{l}\text { Use a micronutrient fertilizer, spray with } \\
\text { manganese sulfate at a rate of } 0.5 \mathrm{lbs} / 100 \\
\text { gallons. }\end{array}$ \\
\hline Chlorosis on youngest leaves & $\begin{array}{l}\text { Magnesium deficiency }(\mathrm{Mg}) \\
\text { This is unusual in Ficus since } \mathrm{Mg} \\
\text { deficiency usually occurs in old leaves }\end{array}$ & $\begin{array}{l}\text { Spray or drench with magnesium sulfate, } \\
\text { chelated magnesium, or magnesium nitrate } \\
\text { at recommended rate. }\end{array}$ \\
\hline Decrease in leaf area & Boron deficiency (B) & Drench or spray with borox. \\
\hline $\begin{array}{l}\text { Extreme chlorosis or necrosis } \\
\text { of the youngest leaves }\end{array}$ & Boron toxicity (B) & $\begin{array}{l}\text { Leach soil, remove and stop using any rat or } \\
\text { ant pesticides containing boron in the area. }\end{array}$ \\
\hline Tip burn in older leaves & Sodium toxicity ( $\mathrm{Na})$ & $\begin{array}{l}\text { Leach soil, supplement with potassium and } \\
\text { gypsum. }\end{array}$ \\
\hline $\begin{array}{l}\text { Slimy, necrotic spots on } \\
\text { leaves, mass leaf drop }\end{array}$ & Chilling injury & $\begin{array}{l}\text { Plants should be kept in areas above } 60^{\circ} \mathrm{F} \\
\text { at all times, including shipping and } \\
\text { showcasing. }\end{array}$ \\
\hline
\end{tabular}

